\title{
WHERE DO RISKS IN SHRIMP FARMING COME FROM? EMPIRICAL RESULTS FROM SMALL FARMERS IN EAST JAVA, INDONESIA
}

\author{
Riski A. Lestariadi ${ }^{1 凶}$, Masahiro Yamao ${ }^{1}$ \\ ${ }^{1}$ Hiroshima University, Japan
}

\begin{abstract}
This study was conducted to explore small-scale shrimp farmers' perception of risk and risk management. The data used originated from a field survey in the southern and northern coasts of East Java, Indonesia. According to the results, there are 32 risk sources, including shrimp price volatility and high mortality due to shrimp diseases as the most important ones. The exploratory factor analysis showed that the risks in small-scale shrimp farming derived from 8 factors: input and pond preparation; finance and credit access; production; personal aspects; harvesting and marketing; weather and environment; policy and institutional aspects; and business environment. The results also revealed that the shrimp farmers' perception of risk could significantly influence their risk management behavior. Furthermore, nine factors were identified for risk management strategies, including disease prevention; education and technology improvement; production inputs; farm management; government support; risk sharing and insurance; financial aspects; household adjustment; and alternative income sources.
\end{abstract}

Keywords: risk, risk management, shrimp farming, multivariate analysis, Indonesia

\section{INTRODUCTION}

High risk and uncertainty are the two factors that characterize small-scale shrimp farming. Risks faced by farmers are inherent to all economic activities in shrimp farms as well as to other aquaculture activities. Aquaculture faces several risks that are similar to those encountered in the agricultural sector. However, the risks in aquaculture are diverse in terms of cultivating system and practices, dependence on environmental conditions, and diversity of species. As a result, the range of actual and perceived hazards in aquaculture is much broader than in agriculture. FAO (2008) reported that the risk in aquaculture is greater due to intensified transboundary movement of aquaculture products as a part of increasing market liberalization.

Nowadays, risk environment has been changing (Meeuwissen et al., 2001). In aquaculture, production aspects such as diseases have become the major sources of risk in the last several years. According to Ababouch et al. (2015), the costs of disease outbreaks to the global aquaculture industry reached tens of billions of USD over the last 20 years. Aquaculture also faces risks from other human activities such as contamination of waterways by agriculture and industrial activities (FAO, 2016). Moreover, the shrimp industry alone has suffered losses of around USD 10 billion since 1990, with new diseases emerging almost every year (World Bank, 2014).

As the second largest aquaculture producer in the world, Indonesia has also faced several problems in its

\footnotetext{
*The authors would like to thank the Ministry of Education, Culture, Sports, Science and Technology, Japan for support during this study.
}

$凶$ PhD Riski A. Lestariadi, Graduate School of Biosphere Science, Hiroshima University, 1-4-4 Kagamiyama, Higashi-Hiroshima City, Hiroshima 739-8528, Japan, e-mail: d150559@hiroshima-u.ac.jp 
aquaculture production during the last couple of years. As regards shrimp farming, the spread of diseases, environmental degradation, price fluctuation, and product rejection from importing countries were some of the few issues that affected Indonesian shrimp production (FAO, 2016; Sustainable Fisheries Partnership, 2013; Undercurrent News, 2014). These sources of risks have been pushing shrimp farmers to make risky decisions related to their farms. Risk is defined in many ways. Based on the International Risk Management Principles and Guidelines standard (AS/NZS ISO 31000:2009), it means the effect of uncertainty on objectives (SAI Global, 2009). Moreover, several scholars defined risk as reflecting variation in the distribution of possible outcomes, their likelihood, and their subjective values (Campbell and Stamp, 2004; Conforti et al., 2011; Verbano and Venturini, 2011).

In exploring the risk environment, there are several types of analyses of risk sources and of the levels of their impact on farming activities. One of these types is factor analysis. According to Hoogeveen et al. (2005), the purpose of factor analysis is to understand the correlation structure of risk sources and risk management strategies. Factor analysis is an effective tool for examining the underlying structure of a relatively large set of risk sources and risk management strategies.

A recent study by Ahsan (2011) found 23 sources of risk for shrimp farming in Bangladesh. The exploratory factor analysis has been used to group these sources of risk into seven factors, which are institutional, demand, marketing, business insecurity, input price, political affairs, and credit. The research revealed that institutional risk was the key factor, mostly affected by such sources of risk as corrupt employees and supply of private capital. On the other hand, prevention of diseases is considered among the best strategies to manage the risks in the shrimp farming business.

Related research has been carried out in mussel farms in Denmark and Greece (Ahsan and Roth, 2010; Theodorou et al., 2010). The first study found that significant risks came from the marketing factor. Sources of risk such as future demand, price, and certification of mussel were the most damaging risks for mussel farms. According to the latter study, risks related to financial and personal factors were perceived as the most important ones in risk management at mussel farm level in Greece.

Bergjord (2009) conducted a survey on Norwegian aquaculture and found 39 risk sources. For the strategies, the future salmon price was the most important risk. Subsequently, the exploratory factor analysis was applied to reduce the number of risks into nine factors, and found that marketing factor was the most important one. According to Flatern et al. (2009), the production risk factor significantly affected the dairy farmers' income in Norway. The top three sources of risk for this factor were the epidemic of domestic animal diseases, production diseases, and meat production variability. Based on the exploratory factor analysis, the research identified seven factors of risk management strategies, interpreted as consultancy, disease prevention, flexibility, insurance, diversification, financial aspects, and fixed cost sharing. Further, risk management strategies such as consultancy should make more use of decision analysis tools that take institutional risk into consideration.

The facts mentioned earlier revealed that aquaculture (e.g., shrimp farming) has a highly risky nature which makes the farmers face multidimensional risks. The understanding of small-scale shrimp farmers' risk management strategies is essential for formulating the proper policy to develop and preserve the sustainability of the shrimp industry and the farmers' livelihood. However, the literature in risk management of small-scale shrimp farming, particularly in developing countries (e.g., Indonesia), is scarce. Hence, keeping in mind the importance of risk management strategies in small-scale shrimp farming, the purpose of this study is to investigate the risk behavior of small-scale shrimp farmers in East Java, Indonesia. Specifically, this research had two objectives: (1) to investigate the sources of risk in small-scale shrimp farming and the use of risk management strategies at farm level; (2) to analyze the major risk factors and risk management strategies in the study area. This study is expected to provide essential information to policy makers, enabling a further understanding of risk management in small-scale shrimp farming. Moreover, this study revealed some relevant issues for further research.

\section{MATERIALS AND METHODS}

\section{Materials}

The data used for this research originated from a field survey in the southern and northern coasts of East Java, Indonesia (Fig. 1). Two regencies were selected: (1) Banyuwangi Regency in the south, and (2) Lamongan Regency in the north. The research areas were selected 


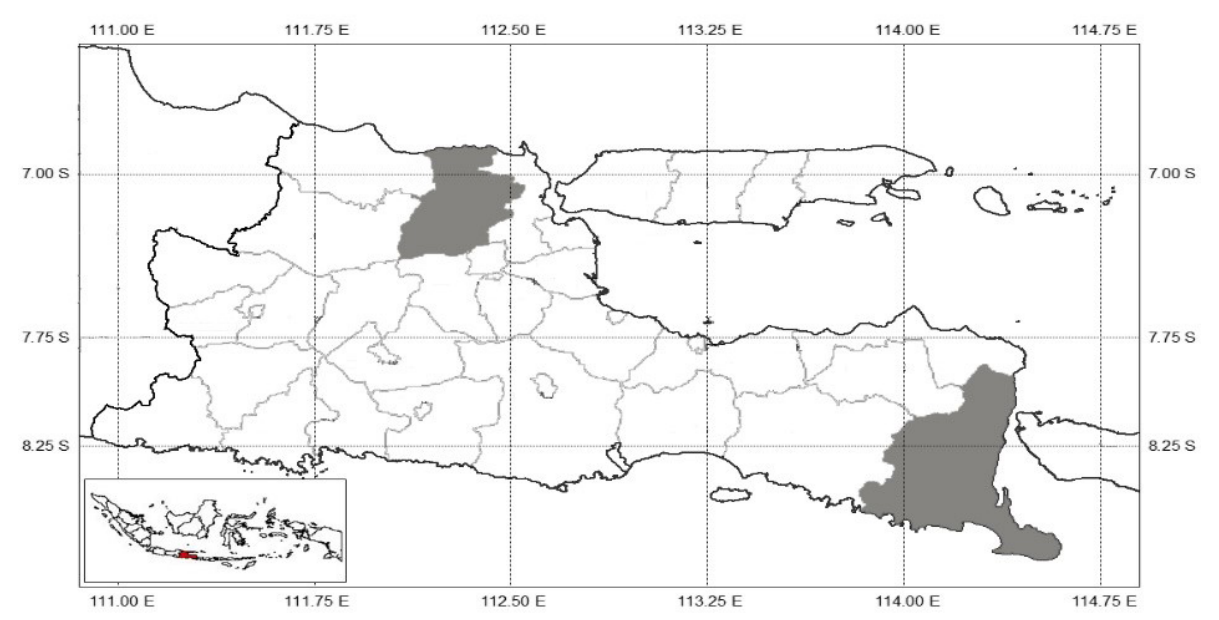

Fig. 1. Study areas in East Java Province, Indonesia

purposively as the main shrimp producing areas in East Java. The sample included 79 and 87 shrimp farms in the south and north, respectively.

A semi-structured questionnaire was used for data collection from small-scale shrimp farms in the study areas. Prior to starting the survey, in-depth interviews with experts in shrimp farming were conducted to avoid missing any important information related to risk sources and risk management strategies. Based on the in-depth interviews, the researchers developed the questionnaire that covered 32 sources of risk; 34 risk-management strategies were presented to the respondents.

The questionnaires consisted of questions related to: 1) socio-economic characteristics of small-scale shrimp farmers; 2) degree of consequences and likelihood of risk sources; and 3) effectiveness of risk management strategies. The total number of questionnaires (166) were administered and completed. In this research, a five-point Likert scale was used to measure the consequences (from $1=$ minor impact to $5=$ severe impact) and the likelihood (from $1=$ rare to $5=$ almost certain occurrence) of risk sources. To measure the potential impact of risk sources, the concept of risk levels was used. The level of risk is defined as the product of consequence and likelihood of risk (i.e. level of risk = consequences $\times$ likelihood). Afterwards, the risk level score (ranging from $1=$ least significant to $5=$ most significant) is used for the analysis. The effectiveness of risk management strategies was also measured with a five-point Likert scale, ranging from 1 (= not effective at all) to 5 (= very effective).

\section{Methods}

As the first step, the shrimp farmers' perception of risk sources and risk management strategies were studied using descriptive statistical analysis. Afterwards, the exploratory factor analysis was performed by examining the pattern of correlations between the variables observed. Highly correlated variables (represented by a high loading factor, either positive or negative) are likely influenced by the same factor, and vice versa. To comply with the assumptions of the analysis, the factor analysis application condition was checked using the correlation coefficient matrix, the Kaiser-Meyer-Olkin (KMO) measure of sample adequacy, and Bartlett's test of sphericity.

The factor analysis is the most popular multivariate technique used to assess the variability among variables in data sets (Gebreegziabher and Tadesse, 2014). In this study, the data set consists of variables related to risk sources and risk management strategies. As explained by Qasim and Ahmad (2016), the purpose of the exploratory factor analysis is to find a way of condensing the information contained in several original variables into a smaller set of a new composite dimension (factor). Moreover, the eigenvalues express the degree of variation among variables in each factor. As a guideline, the eigenvalue score $>1$ was used to determine the number of factors to be extracted (Bagheri and Fami, 2016; Flaten et al., 2005; Hair et al., 1998). 


\section{RESULTS AND DISCUSSIONS}

This section presents the result of the factor analysis of risk sources and risk management strategies for smallscale shrimp farming in East Java, Indonesia. The exploratory factor analysis was applied to reduce a large number of risk sources and risk management strategies into several factors. The factors extracted and obtained from the present study are presented in Table 1 and Table 2 , respectively.

\section{Sources of risk in small-scale shrimp farming in East Java}

This research uses the concept of risk levels to measure the possible impact of each risk. The level of risk is defined as the product of consequences and likelihood. A total of 32 risk sources were identified in smallscale shrimp farming in the study areas (see Table 1, column 1).

Among the risk sources, shrimp price volatility and high mortality due to diseases were identified as the most significant ones, with a score of 21.90 and 21.84 , respectively (see Table 1, column 2). The second level, with risk scores ranging between 15.01 and 20.00, includes two sources of risk. Shown in Table 1, the second level consisted of risks related to increasing formulated feed price (18.73) and water pollution due to excessive formulated feed (15.92). The next 19 risk sources, with a risk score ranging from 11.00 to 15.00 and with corresponding ranks from 5 to 23, constituted the third (moderately significant) level of risk. Finally, nine sources of risk with a level of risk score varying from 5.00 to 10.00 were classified at the fourth (slightly significant) level. However, none of the risk sources was classified at an insignificant level.

As regards the risk level in Table 1, small-scale shrimp farmers in East Java focused on several risk sources affecting the financial aspect of their shrimp farms. These risk sources consisted of shrimp price volatility and increasing formulated feed price. This reflected not only the fact that shrimp farmers run their enterprises without any price insurance but also the very high level of uncertainty in shrimp farming. The underlying reason for this condition was an imbalance of supply and demand in the market due to spread of shrimp diseases in the last couple of years. As reported in several studies, various kinds of shrimp diseases, such as the Infectious Myonecrosis Virus (IMNV), White Spot Syndrome
Virus (WSSV) and White Feces Disease (WFD) led to significant losses for shrimp farmers (Kilawati, 2015). Therefore, it is not surprising that high mortality due to diseases was the second ranked source of risk.

Furthermore, the total of 32 risk sources were reduced using the Varimax rotation factor analysis to gain a deeper understanding of small-scale shrimp farmers' perception of risk sources. Prior to conducting the exploratory factor analysis, the assumptions of factor analysis were verified using the Kaiser-Meyer-Olkin (KMO) test and Bartlett test. As shown by the results, the KMO was 0.644 , and the Bartlett test was statistically significant at 0.01. Referring to Hair et al. (2006), these results mean the data was satisfactory for factor analysis. Based on this justification, the 32 risk sources were reduced into eight factors.

The factors 1 to 8 could be best denoted as: (1) Input and pond preparation, (2) Finance and credit access, (3) Production, (4) Personal aspects, (5) Harvesting and marketing, (6) Weather and environment, (7) Policy and institutional, and (8) Business environment. These factors explained $73.1 \%$ of the total variance observed. The highest loading items, total variance and extracted factors are shown in the fourth, fifth and sixth columns in Table 1, respectively. After checking for non-significant levels of loading items, no risk sources were removed.

As regards the factor extracted, the results revealed that factor 1, namely "input and pond preparation," explained $12.74 \%$ of the variation observed. Several risk sources, such as low quality of shrimp fries, not enough formulated feed supply, and low quality of formulated shrimp feed, were high loading factors among the risk sources in this group. The results showed that the problems of input and pond preparation triggered shrimp diseases in the study areas. In line with this, a recent survey by Ahsan (2011) on risk management strategies in shrimp industry in Bangladesh indicated that shrimp diseases were identified as the top-rated source of risk and the greatest threat to coastal shrimp farming.

Factor 2, "finance and credit access," had a relatively high loading of increasing formulated feed price and not enough capital to operate shrimp farms. This finding showed that formulated feed price could have a major impact on the shrimp farmers' income. A recent study by Hung and Quy (2013) also noted that the cost of formulated feed represented $66 \%$ to $68 \%$ of the total production cost in the intensive shrimp farming system. 
Lestariadi, R. A., Yamao, M. (2018). Where do risks in shrimp farming come from? Empirical results from small farmers in East Java, Indonesia. J. Agribus. Rural Dev., 1(47), 39-47. http://dx.doi.org/10.17306/J.JARD.2018.00366

Table 1. Risk levels and factors extracted for risk sources

\begin{tabular}{|c|c|c|c|c|c|}
\hline Risk sources & $\begin{array}{l}\text { Risk level } \\
\text { score* }\end{array}$ & Rank & $\begin{array}{l}\text { Highest } \\
\text { loading factor }\end{array}$ & $\begin{array}{l}\text { Total variance } \\
\text { explained }(\%)\end{array}$ & Factor extracted \\
\hline Low quality of shrimp fries & 14.96 & 5 & 0.87 & \multirow{8}{*}{12.74} & \multirow{8}{*}{$\begin{array}{l}\text { input and pond } \\
\text { preparation }\end{array}$} \\
\hline Not enough formulated feed supply & 13.75 & 6 & 0.84 & & \\
\hline Low quality of formulated shrimp feed & 13.29 & 9 & 0.77 & & \\
\hline Inappropriate pond location & 11.25 & 17 & 0.74 & & \\
\hline Treatment not conducted before stocking shrimp fries & 11.04 & 18 & 0.69 & & \\
\hline Inappropriate pond design & 10.53 & 22 & 0.60 & & \\
\hline Inappropriate shrimp fries size & 9.12 & 27 & 0.61 & & \\
\hline Insufficient labor supply & 8.37 & 29 & 0.47 & & \\
\hline Increasing formulated feed price & 18.73 & 3 & 0.88 & \multirow{5}{*}{12.68} & \multirow{5}{*}{$\begin{array}{l}\text { finance and credit } \\
\text { access }\end{array}$} \\
\hline Not enough capital to operate shrimp farms & 13.53 & 8 & 0.79 & & \\
\hline Lack of collateral for loans & 10.87 & 19 & 0.74 & & \\
\hline High interest rate for loans & 8.95 & 28 & 0.74 & & \\
\hline High wages of hired labor & 7.76 & 31 & 0.7 & & \\
\hline High mortality due to diseases & 21.84 & 2 & 0.74 & \multirow{5}{*}{11.79} & \multirow{5}{*}{ production } \\
\hline Water pollution due to excessive formulated feed & 15.92 & 4 & 0.72 & & \\
\hline Feeding management failure & 13.19 & 10 & 0.67 & & \\
\hline Excessive stocking density & 12.21 & 13 & 0.65 & & \\
\hline Brackish water quality & 10.23 & 23 & 0.64 & & \\
\hline Absence of a brackish water treatment facility & 13.75 & 7 & 0.83 & \multirow{5}{*}{11.41} & \multirow{5}{*}{ personal aspects } \\
\hline Lack of knowledge on how to prevent shrimp diseases & 12.67 & 11 & 0.81 & & \\
\hline Lack of information about shrimp fries' origin & 11.49 & 15 & 0.80 & & \\
\hline Lack of knowledge on pond preparation & 11.31 & 16 & 0.60 & & \\
\hline Lack of labor knowledge & 10.73 & 20 & 0.62 & & \\
\hline Shrimp price volatility & 21.9 & 1 & 0.70 & \multirow{4}{*}{7.09} & \multirow{4}{*}{$\begin{array}{l}\text { harvesting and } \\
\text { marketing }\end{array}$} \\
\hline Shrimp size variability & 10.56 & 21 & 0.61 & & \\
\hline Inappropriate harvesting method & 9.69 & 24 & 0.50 & & \\
\hline Harvesting without grading & 9.56 & 25 & 0.41 & & \\
\hline Polluted brackish water sources & 12.6 & 12 & 0.80 & \multirow{2}{*}{6.24} & \multirow{2}{*}{$\begin{array}{l}\text { weather and } \\
\text { environment }\end{array}$} \\
\hline Flood & 7.79 & 30 & 0.64 & & \\
\hline Changing government policies and regulations & 12.17 & 14 & 0.67 & \multirow{2}{*}{6.23} & \multirow{2}{*}{$\begin{array}{l}\text { policy and } \\
\text { institutional }\end{array}$} \\
\hline Low level of awareness in the community & 7.34 & 32 & 0.62 & & \\
\hline $\begin{array}{l}\text { Asymmetric information flow between buyers and } \\
\text { farmers }\end{array}$ & 9.36 & 26 & 0.53 & 4.94 & $\begin{array}{l}\text { business } \\
\text { environment }\end{array}$ \\
\hline
\end{tabular}

* Risk level score: $1-5=$ least significant; $6-10=$ slightly significant; $11-15=$ moderately significant; $16-20=$ significant; $21-25=$ most significant.

Source: own research. 
High mortality due to diseases, water pollution due to excessive formulated feed, and feeding management failure had a strong load as a part of factor 3 of the 'production' risks. This factor explained $11.79 \%$ of the variation observed. Production risk is one of the essential problems in aquaculture and agriculture activities. Several authors reported similar results with a high loading of diseases as a part of production risk (Flaten et al., 2005; Gebreegziabher and Tadesse, 2014; Meeuwissen et al., 2001). The high loading of shrimp diseases in the 'production' risk is likely to reflect the small-scale shrimp farmers' concern for shrimp mortality. Moreover, Bush et al. (2010) stated that the complexity of shrimp farming was due to a close relationship between social and ecological systems. Lack of knowledge on how to prevent diseases was making that business riskier.

Small-scale shrimp farmers are also affected by risks associated with the 'personal' risk factor which explained $11.41 \%$ of the variation observed. As regards personal risk, lack of knowledge on how to prevent shrimp diseases, lack of information about shrimp fries' origin, and lack of knowledge on pond preparation were the highest loading factor. Small farmers tended to use their experience in managing their shrimp ponds. Hence, the personal risk associated with the lack of knowledge in shrimp farms management was a real constraint in maintaining their livelihood and sustainability of the shrimp industry in East Java, Indonesia.

The "harvesting and marketing" risk in factor 5 was mostly affected by shrimp price volatility and shrimp size variability. Harvesting and marketing risk sources were associated with an oversupply of shrimp in the market and inappropriate harvesting methods. Several studies also noted that marketing risk was considered as one of the most significant risk sources in aquaculture and agriculture (Ahsan, 2011; Ahsan and Roth, 2010; Bergfjord, 2005).

The sixth factor, "weather and environment" risk, includes polluted brackish water source and flood. This factor explained $6.24 \%$ of the variation observed. Furthermore, changing government policies and low level of awareness in the community about environmental protection loaded strongly on factor 7 of the "policy and institutional" risk. Last, the "business environment" risk on factor 8 , which explained $4.94 \%$ of the variation observed, was associated with asymmetric information flow between buyers and farmers. The same research finding had supported the study of Ahsan (2011) about shrimp farmers' motivation, risk perception and risk management strategies in Bangladesh which stated that shrimp production involves a complex supply chain. Thus, the operations of intermediaries in shrimp farming were considered to be a major source of risk.

\section{Risk management strategies in small-scale shrimp farming}

In this study, 35 risk management strategies were rated on a five-point Likert scale by shrimp farmers with respect to their efficiency in mitigating each source of risk. The average scores and ranks of strategies are presented in the second and third column of Table 2 . As shown by the results, 16 risk management strategies were classified as very effective in coping with shrimp farming risks, with an average score ranging between 4.1 to 5.0. Strict management of water quality, strict feeding management, applying better management practices, preventing shrimp diseases by regular inspections, and reducing brackish water pond size were the top five strategies in this category. The second group included ten strategies, and had an average score ranging between 3.1 and 4.0 with corresponding ranks from 17 to 26 . The subsequent six risk management strategies, such as changing the consumption pattern, use of largesized shrimp fries, informal marketing contract with the wholesaler, applying new technology, using family labor, and dissaving, were classified as medium effective. Last, only three strategies were categorized as poorly effective (ranging from 1.1 to 2.0), which included sharing the machinery and paddle wheel, following the government policy and regulations, and off-farm work.

Although shrimp price volatility was perceived as the most damaging source of risk (see Table 1, column 3 ), the management strategy addressing that risk (such as production contract), was not perceived to be the most effective one (see Table 2, column 3). The research found that small-scale shrimp farmers preferred to rely on their day-to-day activities to cope with the risk and maximize their income. Several strategies, such as strictly managed water quality, strict feeding management, and applying better management practices, were more effective in addressing the risk in their shrimp farms.

Moreover, the factor analysis with Varimax rotation was applied to reduce many risk management strategies. Thus, nine factors loadings were obtained for risk management strategies in the areas covered by this study. Together, they explained $83.61 \%$ of the total cumulative 
Lestariadi, R. A., Yamao, M. (2018). Where do risks in shrimp farming come from? Empirical results from small farmers in East Java, Indonesia. J. Agribus. Rural Dev., 1(47), 39-47. http://dx.doi.org/10.17306/J.JARD.2018.00366

Table 2. Rank of risk management strategies and factors extracted

\begin{tabular}{|c|c|c|c|c|c|}
\hline Risk management strategies & Mean* & Rank & $\begin{array}{l}\text { Highest load- } \\
\text { ing factor }\end{array}$ & $\begin{array}{l}\text { Total variance } \\
\text { explained }(\%)\end{array}$ & Factor extracted \\
\hline Strictly managing water quality & 5 & 1 & 0.92 & \multirow[t]{8}{*}{17.32} & \multirow{8}{*}{$\begin{array}{l}\text { Disease } \\
\text { prevention }\end{array}$} \\
\hline Strict feeding management & 4.99 & 2 & 0.86 & & \\
\hline Partial harvest & 4.67 & 8 & 0.85 & & \\
\hline Reducing brackish water pond size & 4.78 & 5 & 0.85 & & \\
\hline Reducing stocking density & 4.22 & 12 & 0.77 & & \\
\hline Preventing shrimp disease by regular inspections & 4.79 & 4 & 0.74 & & \\
\hline Reallocating shrimp pond to a designed area & 4.11 & 16 & 0.51 & & \\
\hline Developing a brackish water treatment facility & 3.54 & 19 & 0.46 & & \\
\hline Attending workshops on shrimp farming & 4.55 & 9 & 0.92 & \multirow[t]{2}{*}{16.01} & \multirow{2}{*}{$\begin{array}{l}\text { Education and } \\
\text { technology } \\
\text { improvement }\end{array}$} \\
\hline Applying new technologies in shrimp production & 2.38 & 30 & 0.81 & & \\
\hline Only buying shrimp fries from reliable suppliers & 4.14 & 14 & 0.85 & \multirow[t]{5}{*}{9.53} & \multirow[t]{5}{*}{ Production input } \\
\hline Only buying SPF-certified shrimp fries & 4.41 & 11 & -0.77 & & \\
\hline Buying formulated feed from reliable brands & 3.5 & 20 & 0.67 & & \\
\hline Buying shrimp fries from public hatchery & 3.02 & 26 & 0.64 & & \\
\hline Using large size shrimp fries & 2.76 & 28 & 0.61 & & \\
\hline Applying better management practices & 4.91 & 3 & 0.91 & \multirow[t]{4}{*}{8.42} & \multirow[t]{4}{*}{ Farm management } \\
\hline Hiring a technical assistant & 3.44 & 22 & 0.86 & & \\
\hline Reinforcing the shrimp pond dyke & 3.43 & 23 & 0.57 & & \\
\hline Following the government policy and regulations & 1.22 & 34 & 0.47 & & \\
\hline Requesting technical assistance from the government & 4.14 & 15 & 0.78 & \multirow[t]{2}{*}{7.85} & \multirow{2}{*}{$\begin{array}{l}\text { Government } \\
\text { support }\end{array}$} \\
\hline Requesting social assistance after a natural disaster & 3.29 & 25 & 0.62 & & \\
\hline Production contract & 4.77 & 6 & 0.89 & \multirow[t]{7}{*}{6.29} & \multirow{7}{*}{$\begin{array}{l}\text { Risk sharing and } \\
\text { insurance }\end{array}$} \\
\hline Sharecropping & 4.52 & 10 & 0.88 & & \\
\hline Contract on shrimp farming inputs & 4.69 & 7 & 0.65 & & \\
\hline Informal marketing contract with wholesalers & 2.52 & 29 & 0.53 & & \\
\hline Vertical integration & 4.21 & 13 & 0.51 & & \\
\hline Marketing contract with processors & 3.8 & 17 & 0.53 & & \\
\hline Sharing machinery and paddle wheels & 1.96 & 33 & 0.47 & & \\
\hline Using informal loans & 3.72 & 18 & 0.65 & \multirow[t]{3}{*}{6.21} & \multirow[t]{3}{*}{ Financial aspects } \\
\hline Making credit arrangements before production cycle & 3.45 & 21 & 0.86 & & \\
\hline Dissaving & 2.09 & 32 & 0.56 & & \\
\hline Changing the consumption patterns & 2.76 & 27 & 0.53 & \multirow[t]{2}{*}{6.01} & \multirow{2}{*}{$\begin{array}{l}\text { Household } \\
\text { adjustment }\end{array}$} \\
\hline Using family labor & 2.11 & 31 & 0.54 & & \\
\hline Farm diversification & 3.29 & 24 & 0.82 & \multirow[t]{2}{*}{5.96} & \multirow{2}{*}{$\begin{array}{l}\text { Alternative in- } \\
\text { come sources }\end{array}$} \\
\hline Off-farm work & 1.2 & 35 & 0.64 & & \\
\hline
\end{tabular}

* Mean of risk management strategies: $0.0-1.0=$ not effective at all; $1.1-2.0=$ poorly effective; $2.1-3.0=$ medium effective; 3.1-4.0 $=$ effective; $4.1-5.0=$ very effective.

Source: own research. 
variance. The last three columns in Table 2 present the loading items, total variance, and factors extracted. Factors from 1 to 9 in Table 2 were identified as: (1) Disease prevention, (2) Education and technology improvement; (3) Production input; (4) Farm management; (5) Government support; (6) Risk sharing and insurance; (7) Financial aspects; (8) Household adjustment; and (9) Alternative income sources.

Factor 1, referred to as "disease prevention," explained $17.33 \%$ of the variation observed. Strictly managing water quality, strict feeding management, and partial harvest were the top three strategies in this group with loading scores of $0.92,0.86$ and 0.85 , respectively. They remained the most effective risk management strategies employed to prevent shrimp diseases and minimize income losses. This research finding was also supported by Kilawati (2015) who stated that shrimp diseases were the key problem for Indonesian shrimp farming during the last several years. Factor 2 represented 'education and technology improvement' by attending workshops on shrimp farming and applying new technologies in shrimp production. These strategies were perceived to be an effective way of risk management in small-scale shrimp farming in East Java. As also indicated by previous studies, the farmers tended to adopt new technologies to enhance production (Ahsan, 2011; Ahsan and Roth, 2010; Bergfjord, 2009).

Factor 3, identified as "production input," includes a high loading of risk management strategies associated with management of input in shrimp farms, such as only buying shrimp fries from reliable suppliers and buying formulated feed from reliable brands. Factor 4 (farm management) included internal management strategies for shrimp farms. As regards this factor, high loadings were reported for the following strategies: applying better management practices, hiring a technical assistant, reinforcing the shrimp pond dike, and following the government policy and regulations.

Two risk management strategies, which are requesting technical assistance from the government and requesting social assistance after a natural disaster, were grouped into factor 5 (government support). Factor 6, "risk sharing and insurance," includes high-loading risk management strategies associated with the shrimp farmers' efforts to share their risk with third parties. Seven strategies are listed in this factor, including production contract, sharecropping, contract on farm inputs, informal marketing contract, vertical integration, and marketing contract with wholesalers. Ahsan and Roth (2010) obtained similar results regarding risk management for mussel aquaculture in Denmark. They found that cooperative marketing was one of the important strategies to mitigate the impact of risk on the farms.

Three strategies were grouped into factor 7 , identified as 'financial' strategies. This group had high loadings for the following items: using informal loans, making credit arrangements before production cycle and dissaving. Factor 8 was named 'household adjustment' due to dominant strategies for this factor which are changing the consumption patterns and using family labor, which explained $6 \%$ of the variation observed. Finally, two risk management strategies, such as farm diversification and off-farm work, were classified into factor 9 (alternative income sources). In Greece, Theodorou et al. (2010) found a similar result. For the Greek mussel farmers, the certainty of income from other sources was the preferred risk management strategy.

\section{CONCLUSIONS}

The objectives of the present study were to provide an empirical insight into the small-scale shrimp farmers' perception of risk sources and risk management strategies. The results found 32 sources of risk. Shrimp price volatility and high mortality due to shrimp diseases were the most important risk sources for small-scale shrimp farming in East Java, Indonesia. The spread of shrimp diseases in the last several years has been affecting the shrimp farmers' perception of risk in their shrimp farms.

Moreover, as shown by the results, the shrimp farmers' perception could significantly influence their risk management behavior. Small-scale shrimp farmers' have relied on 35 strategies to cope with the risk in their farms. The top five strategies in small-scale shrimp farming included strict management of water quality, strict feeding management, applying better management practices, preventing shrimp diseases by regular inspections, and reducing the brackish water pond size.

The exploratory factor analysis showed that the risks in small-scale shrimp farming derived from 8 factors: input and pond preparation; finance and credit access; production; personal aspects; harvesting and marketing; weather and environment; policy and institutional aspects; and business environment. These factors explained $73.1 \%$ of the variation observed. Furthermore, 
nine factors were identified for risk management strategies, including disease prevention; education and technology improvement; production inputs; farm management; government support; risk sharing and insurance; financial aspects; household adjustment; and alternative income sources.

To conclude, identifying such risk sources and risk management strategies could contribute to a better understanding of the nature of risk and uncertainty in small-scale shrimp farming. This could be followed by suggesting effective strategies for risk management at farm level. The research findings are expected to contribute for policymakers to design policies and regulations that support the sustainability of shrimp industry, especially at a small scale.

\section{REFERENCES}

Ababouch, L. C. (2015). Fisheries and aquaculture utilization and trade. Geneva: FAO.

Ahsan, A. D. (2011). Farmers' motivations, risk perceptions and risk management strategies in a developing economy: Bangladesh experience. J. Risk Res., 325-349.

Ahsan, D. A., Roth, E. (2010). Farmers' perceived risks and risk management strategies in an Emerging Mussel Aquaculture Industry in Denmark. Marine Res. Econ., 25, 309-323.

Bagheri, A., Fami, H. S. (2016). Potato growers' risk perception: a case study in Ardabil Province of Iran. J. Agr. Sci. Tech., 55-65.

Bank, W. (2014). Reducing diseases risk in aquaculture. World Bank Group.

Bergfjord, O. J. (2009). Risk perception and risk management in Norwegian aquaculture. J. Risk Res., 12(1), 91-104.

Bush, S. R., Zwieten, P. A., Visser, L., Dijk, H. V., Bosma, R., Boer, W. F., Verdegem, M. (2010). Scenarios for resilient shrimp aquaculture in tropical area. Ecol. Soc., 15, (2), 15.

Campbell, P. L., Stamp, J. E. (2004). A classification scheme for risk assessment methods. Sandia National Laboratories, Oak Ridge.

FAO (2008). Understanding and applying risk analysis in aquaculture. Food and Agriculture Organization of the United Nations. Rome: FAO.
FAO (2016). The state of world fisheries and aquaculture: opportunities and challenges. Rome: FAO.

Flaten, O., Lien, G., Koesling, M., Valle, P. S., Ebbesvik, M. (2005). Comparing risk perceptions and risk management in organic and conventional dairy farming: empirical results from Norway. Livest. Prod. Sci., 95, 11-25.

Gebreegziabher, K., Tadesse, T. (2014). Risk perception and management in smallholder dairy farming in Tigray, Northern Ethiopia. J. Risk Res., 17(3), 367-381.

Hair, J. F., Black, W. C., Babin, B. J., Anderson, R. E., Tatham, R. L. (1998). Multivariate data analysis. Uppersaddle River. Multivariate Data Analysis (5th ed) Upper Saddle River.

Hung, L. T., Quy, O. M. (2013). On-farm feeding and feed management in whitleg shrimp (Litopanaeus vannamei) farming in Vietnam. In: M. N. Hasan, M. B. New (Eds.), On-farm feeding and feed management in aquaculture (pp. 337-357). Rome: FAO Fisheries and Aquaculture, Technical Paper No. 583.

Kilawati, Y. M. (2015). ICP11 as biomarker for WSSV diseases in Litopanaeus vannamei. Res. J. Life Sci., 2(3), 183-188.

Meeuwissen, M. H., Huirne, R. B., Hardaker, J. B. (2001). Risk and risk management: An empirical analysis of Dutch livestock farmers. Livest. Prod. Sci., 43-53.

Partnership, S. F. (2013). Sustainable shrimp industry. Surabaya: Sustainable Fisheries Partnership.

Qasim, M., Ahmad, N. (2016). Agricultural risk sources and risk management strategies: the case of rain-fed agriculture in Pothwar region, Punjab, Pakistan. J. Appl. Environ. Biol. Sci., 6(3), 18-25.

SAI Global (2009). AS/NZS ISO 31000 : 2009, Risk management : principles and guidelines. Standards Australia, Sydney, N.S.W.

Theodorou, J. A., Tzovenis, I., Sorgeloos, P., Viaene, J. (2010). Risk perception and risk management strategies of Greek mussel farmers. IIFET (p. 1-6). Montpellier: IIFET.

Undercurrent News (2014). Indonesian farmers report panic selling on falling shrimp prices. Retrieved from: https:// www.undercurrentnews.com/2014/05/27/indonesianfarmers-report-panic-selling-on-falling-shrimp-prices/.

Verbano, C., Venturini, K. (2011). Development Paths of Risk Management: Approaches, Methods and Fields of Application. J. Risk Res., 14(5-6), 519-550. 